\title{
O DOMÍNIO DA FERRAMENTA COMPUTACIONAL NO TRATAMENTO DE IMAGENS
}

\author{
Evelise Anicet Rüthschiling ${ }^{*}$
}

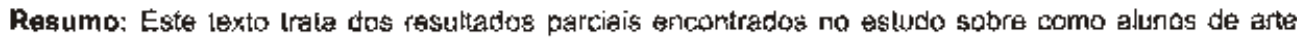

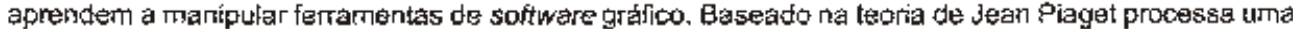
análise epistenologka. Este estudo aponta as operaços logicas e infra-logicas que sao procossadas pelo racibelilo do estudante, wisando dominar as operasoses das teramentas computacionais para crias suac finagens com liberdade.
\end{abstract}

Pałavras-chawe: Auto-organizacajo; criaço de imagens; interaça homem/mápuina.

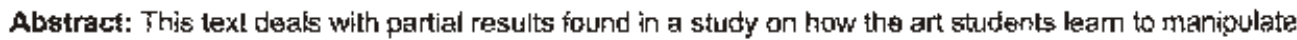
the graphic software tools. Based on Jian Piaget theory processes an epistematogingl analysis. This study points out the logle and the infra-logic operations that are processed by art students reasoning in order to dominate the sothwere toots to create their images with fiesorom.

Key -words: auto-organization; ismage crealion; interaction manimachine

\section{Introduçăa}

Os ambientes informatizados constituem parte integrante da sociedade contemporânea, com os quais o individuo certamente ira interagir, e, consequentemente; conthecé-los. Para mutos se apresentam como abstàculos a serem vencidos, enquanto que outros enumeram suas vantagens. O suporte eletrônico trabalha em nivel de simulaçăo, que sabemos que näo substitui a experiência concreta, mas revela um novo modo de vivência do fazer, ampliando as possibilidades cognitivas encuquanto tambèm apresenta uma dimensāo virtual do real.

O fato é que o avanço da tecnologia chega até nós independente da nossa vontade, mudando tofalmente o modus wivendi a que estavamos acostumados. Traz consigo experięncias novas e com elas certas vantagens em relaçäo ao fazer concreto, por exemplo, a possibilidade de acompanhar cursos à distancia, experimentar açōes que na vivẻncia concreta oferecem riscos, ter acesso a informeçōes distantes, dentre outras. O computador vem assumindo o papel do "melhor amigo do nomem", principalmente no sentido de siminuir o "trabaho braçal", ampliando as condiçoes do individuo desenvolver seu intelecto, sua criatividade integração com seus pares (comunicaçäo).

O presente texto é a primeira tentativa de análise do fenômeno de aprendizado observado no decomer das disciplinas de "Design de Supefficje I e Il" do curso de Bacharelado em Artes Pfásticas da Universidade Federal do Rio Grande do Sul no primeiro semestre tetivo de 1999 sob a ótica da "auto-organizaçäo" e "autopoiese" frabalhadas intensamente no "Seminário de Auto-organizaçăo e Autopojese na perspectiva do conhecimento", ministrado pela Profa. Dra. Margarete Axt, como disciplina do PPGIE - Programa de PósGreduaçäo em łnformática na Educação da UFRGS.

Como situaçăo inicial temos alunos do terceito grau que chegam nessas disciplinas com diferentes backgrounds quanto ao nivel de conhecimento prévio da linguagem visual do design de superficie, farriliaridade com o uso de computador e de adiantamento que se encontram no curso de artes. As turmas costumam ser de dez alunos, de idades e interesses vartados. O elemento unificador é que sāo todos alunos de artes, que procuram o design como uma possibilidade que se apresenta de aplicação do processo criativo em tarefas profissionais no mercado de trabaltho e que anseiam peto contato com as novas tecnologias computacionais, como uma forma de se apoderarem de um novo repertório visual oferecido pelos programas gráficos, mas de uma forma ainda sem consciência do que este novo mundo possa oferecer.

O que se observou $\dot{\hat{u}}$ que, com este perfil de aluno, chegamos ao finat do semestre com uma boa coleçāo de trabahos individuais realizados com o programa computacional Design \& Repeat, da knfo Design. Ned Graphics. Em outras palayras, independente do nivel de iniciaçāo do aluno com ambientes informatizados, as metas que cada um se impôs foram atingidas com sucesso.

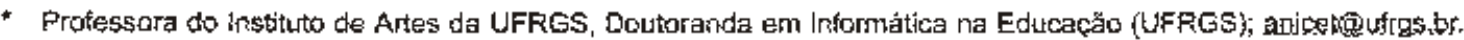


A metodotogia usada foi baseada no "Fazer e Compreender" de Jean Piaget (P|AGET, 1978), que busca esclarecer a questä́ epistemológica fundamental das relaçōes entre a técniça e a ciéncia, que nós estendemos a arte. Esta escolha foi feita pela afinidade ideológica no que diz respeito à crença em construçōes téricas a partir de um fazer prático (a açăo) como forma primeira do conthecer (operaçāo mental). 0 estudo da psicogènese do conhecimento é vastissimo e se fundamenta na observaçăo das açōes e deduçōes do sujeito, buscando compreender as mecanismos lógicos adotados para soluçäo dos probiemas. Săo observados aqui alguns caminhos adotados pelo aluno como estratégia de "conhecer" seu objeto de interesse visando a seu posterior controle. Interessa tentar identificar como o aluno organiza os recursos que dispōe de raciocinio (auto-organizaça) para obter o domínio da ferramenta computacional, colocando-a posteriormente a serviço de sua invenção, o que entendemos como "criação", sua "autopoiese". Cabe esclarecer que o termo "autopoiese" fo inventad o por Humberto Maturana (MATURANA, 1997) para falar da organização circular do ser vivo, isto 6 , um sistema cujos componentes săo capazes de produzir os elementos necessários à manutenção de sua própria integridade. Este construto foi criado a partir de palavras gregas que significam "para si mesmo" $\theta$ "produzir", "criar", "construir". No dominio das "artes", "poiesis" sermpre significou "criaçăo" e a nova conotação projeta a condiçáo de continuar auto-produtivo. Entendemos auto-organizaçáo como a necessidade de gerar uma estrutura para abrigar o nowo conhecimento, que, por sua vez se estabelece como representaçáo mental do apreendido versus o quê se pode fazer com ele. Para Piaget:

"Conhecer nảo consiste, con efeito, en copiar o real mas em agir sabre ale a transfomá-lo ina aparência ou na realidade), de maneira a compreendê-lo em funçăo dos sistemas de transformaçâo aos quais estäo ligadas estas aços." (PIAGET, 1973)

A proposta prática na condução dos encontros com os alunos desenvolveu-se seguindo a linha construtivista de incentivar o aluno a construir seus conhecimentos a partir de sua maneira própria de interagir com o objeto de estudo, que era, neste caso, o domínio da linguagem do design de superfície e do uso de ferramentas computacionais como meio para atingir esse fim. O professor permanecia na postura de incentivador e como presença para eventual apojo conceitual e técnico. Os alunos eram encorajados a interagir diretamente com o software de forma exploratónia, compartilhada com o grupo. Desta maneira foram passando pelas etapas de evoluçäo do conhecimento deteminadas por Piaget e sua equipe de pesquisadores.

De foma sintética, o desenvolvimento da inteligência e do conhecimento resulta das interações entre o sujeito cognitivo o objeto cognosclvel. Parte de açöes simples a complexas. A passagem dessa forma prática de conhecimento - o "savoir faire" (saber fazer) - transformando esquemas de ação ent esquemas de operaçōes, ocorre quando o sujeito consegue identificar em suas próprias açöes certas caracterlsticas "observaweis" que asseguraram seu éxito, registra em sua consciència a compreensão conceitualizada, da-se a "tomada de consciéncia". Em outras palavras, primeiro ele sabe fazer, ele "consegue" fazer, depois parte para 9 "compreender", que já envolve a tomada de consciência, quando ele explica como "faz". Entre o nivel da "açăo" e da "conceituaçăo" há um nivel intemediário em que ambas atuam em conjunto. O nivel seguinté ó da ultrapassagem da operação sobre a ação. Isto é, a representaçäo da açäo no pensamento com toda sua bagagem da experiéncia vivida, com exitos ou näo, afirmaçöes e negaçöes tornam-se independente da ação, chegando ao ponto de uma "inversăo", quando não é mais preciso repetir a açāo para saber seus efeitos, assim o sujeito pode antecipar o futuro e fazer uso deste seu aprendizado.

Baseados nesta linha de pensamento a seguir apresentamos a descriçăo do sotware com suas características, o que julgamos necessário para uma maior compreensão da terceira parte deste texto, onde serão tratadas as relaçöes entre as operaçöes lógicas e infralogicas do sujeito e as do programa. Para tanto nos apoiamos na teoria de Piaget, mas ja revisitada e aplicada no entendimento das funçóes lógicas oferecidas pelas ferramentas computacionais na tese de doutoramento da Dra. Patricia A. Behar, intitulada "Análise Operatória de Ferramentas Computacionais de Uso Individual e Cooperativo".

Como forma de complementação e demonstraçăo anexamos a descriçăo do caso particular de uma aluna que conseguiu realizar sua proposta sem ter tido experiência prévia nem com os recursos informéticos, nem com a linguagem visual do design de superficie.

De certa forma, apercebemo-nos de que estamos percorrendo as etapas apontadas por Piaget na aquisiçāo do conhecimento quando diante da experiência realizada observamos seus resultados procuramos compreendê-los. Buscamos tomar consciência da causa do éxito na prática pedagógica adotada. Ao escrever, organizamos nosso pensamento, e através da compreensāo conceitualizada registramos o aprendizado adquirido diante dos fenômenos observados. Sob a forma escrita nosso pensamento assume uma forma acesslwek 
pela msioria, sendo possivel convidar o leitor a compartilhar desta experiéncia e conquistá-1o como parceino na busca de respostas mais esclarecedoras.

\section{Descrịça do programa de computador Design \& Repeat}

Este estudo baseou-se na observação e análise da interação do aluno com o software Design \& Repeat da Info Design. Trata-se de um programa do tipo editor gráfico, pois possibilita tanto a criaçáo de imagens através de processos intrinsecos do desenho, como o tratamento de imagens digitalizadas e/ou importadas de outros programas. Sua principal caracteristica é a especialidade em colocar em repetiçáo a forma desenhada (repeat, em inglès, ou rapport, em francês). $O$ objetivo desta funçăo é a futura aplicaçăo das imagens em superficies continuas de uso artistico, artesanal $e$ industrial erm revestimentos têxteis, cerámicos, de papelaria e materiais sintéticos, por exemplo: estamparia em tecidos, papeis de embrutho, jacquard de estofados e malharia, azulejos, fórmica, etc. Para que este efeito se realize com sucesso o programa está equipado com ferramentas potentes para esta finalidade, assim como outras que completam as exigências da linguagem plástica.

O Design 8 Repeat opera sobre a interface "amigfvel" do sistema Windows, cujo ambiente è bastante familiar à maioria dos sujeitos usuários. Os instrumentos de comando podem ser o teclado (algumas funçōes pedem a entrada de dados soh a forma de números, unidades de medidas, etc), o mouse ou o tablete com caneta sensiłiva que atuam como melo nas interaçóes entre o sujeito e o objeto - o programa - desencadeando operaçōes infralógicas das diferentes ferramentas, cujas funçōes sāo pré-definidas na programaçăo do sistema. O ambiente mostrado na tela do computador oferece icones que simbolizam as ferramentas que atuam sós e em conjunto com outras, são as chamadas "caixas de ferramentas". 0 acesso a estas funçŏes se dả ativando a ferramente com um "click" en cima do lcone o que permite que o usuário desenthe, faça seleçáo de cores, selecione áreas a serem reaplicadas na própria imagem, assim como modifique a forma de encaixe dos módulos (unidade do desentho que é repetida), dentre outras operaçōes de maripulação direta (dominio total do usuário) ou indireta (a escolha de algumas funçöes previstas no sistema de forma mais autônoma).

Podemas identificar funçōes que pemitem a realização de operaçōes por parte do sujeito usuário. A lógica tem se apresentado como recurso inventado pedo homem para ajudá-lo a desvendar os mistérios de seu

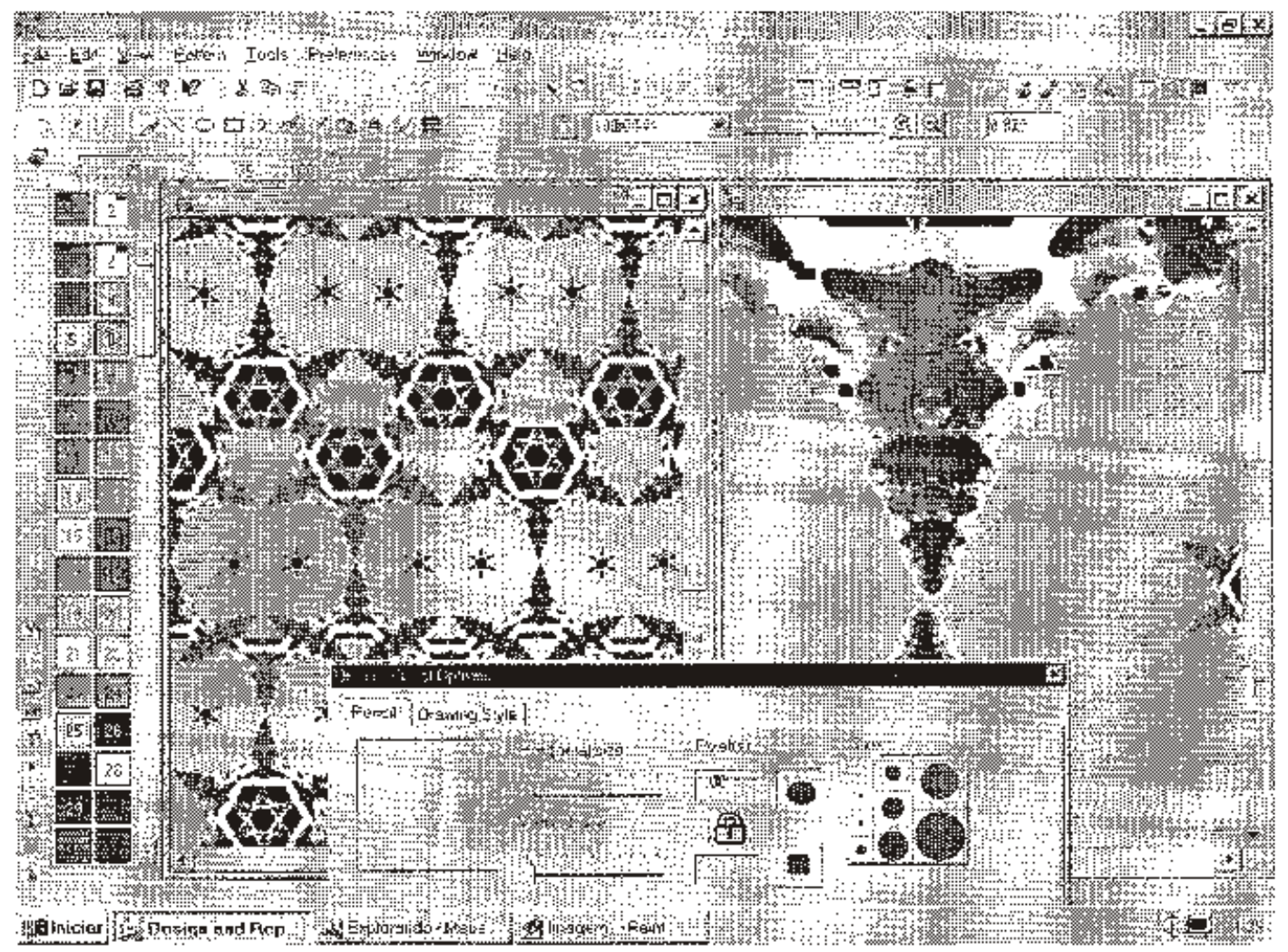

Esta ligura mostra a interface grática do proprama Design Repeat. Apresenta atha a palheta de cores expondo

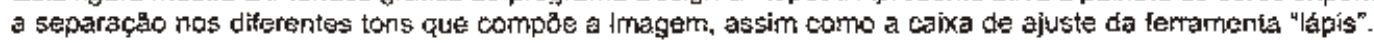


objeto de estudo nos diversos campos do conhecimento. Neste estudo particular vamos nos valer da construçáo feita pela Dra. Patrícja Behar que se apoiou no trabafho de Jean Piaget sobre "Lógica Operatória". Consideramos que esta linha téfica pode nos ajudar pois identifica poss/veis mecarismos do raciocinio no sentido da maior compreensäo do desconhecido.

"Operaçá" para Piaget é a "ação interiorizada ou interiorizàvel, reversivel e coordenada em utma estrutura total" (PIAGET,71; BEHAR, 97) É quando o sujeito detéfn uma representaçāo mental de sua ação e de seus efeitos, possibjitando voltar ao ponto de partida em pensamento, antecipar o resultado na aplicaçáco em novas experiencias, articulando-a com outras açöes, buscando novos efeitos. Quando atuam em conjunto formam os "sistemas de operaçoes" que abrangem a bogica natural do individuo e a logica fomal da matematica. Essas lógicas "consjsten em leis normativas necessálias às trocas de pensamento e, impostas por uma necessidade social, ent oposiçăo à anarquia das representaçöes espontaneas do sujeito" (BEHAR, 97 ). O\$ sistemas de operaça sạo regidos pela "lógica operatória", que consiste em modelos formais que procuram estabelecter relaçōes entre os objetos de um deteminado universo. As operaçós lógicas estabelecem relaçöes de limite espaçotemporal, classificaçäo em classes, agrupando e reunindo os objetos segundo suas propriedades comuns. Classificam e ordenam os objetos segundo suas semelhanças e diferenģas, gerando séries através de operaçöes de adiçác (de determinado objeto a um grupo), subtraçāo, etc..

As "operaçōes infralogicas" tratam das relações internas do objeto, isto é; das partes entre si e das partes com o todo. Mas, isto nāo quel dizer que exista hierarquia entre o nivel lógico para o infralogico, apenas atuam de modos diferentes com os objetos. O termo infralogico está relacionado à noçä́ de objeto, näo se ocupa em classificar, mas em identificar as relaçóes de vizinhança, contiguidade, posiçöo que ocupa no todo. substitui a noção de número (quantos objetos de uma mesma classe) pela de medida da parte em relação ao todo.

Behar reifterpreta o concelto de operação em relaçăo ao sujeito e o transfere para o objeto, entendendo como operaçáo na ferramenta computacionat aquela reajizada pelo sujeito e transferida para a máquina quando executa a açáo.



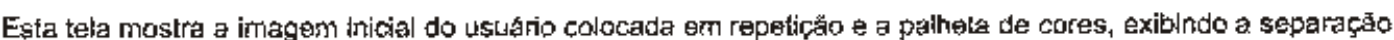
nos diferentes tons encontrados pelo sisterna. 
Com um olhar superficial já podemos identificar no programa em análise um mecanismo de controle do sistema subjacente ás operaçoes ofertadas pelas ferramentas, que determinam as operaçöes possiveis para o usuario. Mas as açoes das ferramentas usadas individualmente e/ou combinadas entre si colocam à disposição do usuário um imenso número de possiveis soluçöes formais para cada imagem tratada neste programá. A maioria destas operaçöes podem ser identificadas como infralógicas, por exemplo a açäo de desenhar com linha, usando o tápis ou pincel; preencher àreas com cores diferentes; selecionar partes, recortar e colálas noutra posição. As caixas de propriedades permiterr que o usuário defina atributos da figura como a unidade de medida adotada (inch, crn, dpi, pixed, etc.), a espessura da tinha, a medida do módulo, a alteraçäo da origem de repetiçăo (noção de vizinhança e localizaçăo da parte no todo), a palheta de cớes (altemáncia de cor entre figura-fundo) dentre outras funçóes disponibilizadas pelo sistema, trabalham no nivel infralógico. Enquanto que operaçōes do tipo "importar e exportar" arquivos de outros programas podemos identificar como operaçóes lógicas de adiçāo e subtraçăo, carregando o objeto inteiro.

O imbricamento entre as estruturas formais do sujeito com sua lógica natural e as estruturas lógicas projetadas na concepção do sistema computacional determina a abertura para possiveis atualizaçōes da vontade do sujeito, que coloca as ferramentas a serviço de sua atividade criativa. No presente estudo interessa delinear como o aluno consegue dominar as possibilidades expressivas das ferramentas computacionais, colocando-as a servico de seu interesse artístico.

\section{Dominio do sujeito sobre o objeto}

A experiéncia prática realizada com os alunos provocou reflexōes que necessariamente terão que tramar fibras do campo epistemológico com fibras da área arfistica, mais precisamente o processo de criação. $O$ intuito neste momento é procurar estabelecer algumas convergencias existentes entre tais campos e identificar recirsos possivelmente adotados pelas alunos em seu processo de aprendizagem da linguagerm visual do design de superficie através dos mecanismos tecnológicos atuais e de que maneira se apoderaram das fertamentas computacionais para expressar essa linguagem. Para tal usaremos como base as etapas de desenvolvimento do conhecimento identificadas por Jean Piaget, como guia nesta caminhada. Por outro lado, levaremos em consideraçąo tambem suas experiencias que fundamentaram os livros "O possivel e o necessário", "Fazer e Compreender" e "Tomada de Consciencia". A abordagen artistica sera apoiada na tese de Doutoramento da Profa. Tânia Fraga da Silva da UnB, quando trata des características do processo criativo, cuja contribuiçăo exprime o consenso de vários autores por ela pesquisados.

Inicialmente temos um sujeito epistêmico adutto, encarnado no sujeito psicológico, que carrega consigo sua bagagem de sentimentos, memória, afetividade, crenças, valores e experiēncias anteriores que văo determinar seus pensamentos, vontades e maneira de agir na intençäo de realizar açöes com a finalidade de executar um trabalho. $O$ objeto que deverá ser "apreendido" também possuj valores observáveis ou năo, caracteristicas especificas e leis próprias. A interaçáo entre o sujeito e o objeto construirá o conhecimento através de instrumentos de troca tocalizados no meio ambiente. Entende-se por "meio" tudo que toma possivel a realizaçăo de açōes, quer sejam, as regras ou leis identificadas nos dois pólos, sujeito e objeto, quer sejam, a linguagem, ou a interface do computador a as ferramentas do software. Esses instrumentos pemitem a geraçao de funçóes de natureza relacional estabelecidas "entre" o sujeito e o objeto, cujos efeitos săo percebidos nas alteraçōes visuais resultantes do mecanismo inferencial adotado. Em outras palavras, o sujeito deverá se utilizar de recursos de raciocinio para conseguir identificar quais regras sáo comuns a ele e ao objeto, permitir* do a "comunicaçăo" entre eles. Assim o sujeito tem chances de controlar o processo, terminando por dominar o objeto.

Os dados aqui tratados foram coletados a partir da observaçăo das açōes dos alunos, alem de questōes colocadas a eles durante o acompantamento nos encontros. A seguir é apresentado o encadeamento das açōes que definem o processo de aprendizagem do aluno.

\footnotetext{
"... Se nấo existe no começo nem stjeito. no sentido epistemico do temo, nem objetos concebidos como tais, nem, sobretudo, instrumertos invariantes de troca, o problema inicial do conhecimento será, portanto, a de construir tais mediadores: partindo da zona de contato entre o proprio coppo as coisas, eles progredirăontào, cada vaz mais, nas duas direçoses complementares do exterior e do interior, e é essa dupla construçåo progressiva que depente a elaboraçao solidteria do sujeito a dos objetos" (PIAGET: 1990)
} 
No inicio existe o aluno, o computador e o programa computacional, mas eles ainda não estâo colocados em relação. O primeiro passo para desencadear a interaçăo é a açāo corporal do aluno em relaçăo à interface do computador, que pode ser entendida como tal o ambiente wirtual exposto na tela (sofiware), o teciado ou o tablete com caneta sensitiva (perifericos).

O objeto não existe até que o sujeito comece a se interessar por ele e submetê-to às suas açōes. Atos materiais do sujeito em relação ao objeto, acionam funçōes espaço-temporais e causais. O sujeito somente se constituirá como tal quando coordenar livremente suas açōes, caracterizando-se como fonte de açoes e, portanto, de conhecimentos. Gradativamente as açoes väo sendo coordenadas umas às outras, tecendo uma rede de conexőes entre meios e fins, o que Piaget denomina de "assimilaçäo reciproca". Podemos localizar esta etapa quando o aluno descobre que para desenhar com o pincel ele precisa primeiro ativar a ferramenta "clicando" em cima do icone corfespondente e que pode escolher o formato tamanho do pincel acionando a cajxa de fertamentas onde encontram-se as opçōes ofertadas pelo sistema computacional.

Diante da observação do efeito produzido na imagem atualizada na tela do computador a sujeito procura refazer o mesmo gesto ou a açåo na tentativa de reencontrar o mesmo "espetáculo" (expressäo piagetiana) anteriomente desconhecido e nâo esperado por ele. Existem operaç̧ెes e regras nas ferramentas que ainda näo foram desernvolvidas no sujeito, isto é, como ele não as conhece, nāo imagina que seja possivel determinado efeito sobre sua imagem e, por conseguinte, também nāo deseja. Fica evidente esta noção quando o aluno carrega sua magem anteriormente digitalizada para o programa Design \& Repeat. O efeito surpreende pois a imagem se atualiza de forma tepetida, akerando sensivelmente sua visualidade. A primeira reação da maioria dos alunos é de fechar a arquivo e reabri-lo para repetir o "espetaculo". O aluno passa imediatamente a explorar essas alteraçöes, buscando graduar o "zoom" para aumentar ou diminuir o número de repetiçōes e o sistema de encaixe dos módulos ofertado por uma caixa de ferramentas que regula esses encaixes, como é mostrado na figura a seguir. A este processo se dả o nome de "assimilaçâo reproduiora", que é a repetiçāo do gesto até que se tome possivel compreender a relaçāo causa-efeito, fomando-se um novo "esquema de açōes".

Da observaçäo dos efeitos surtidos das açōes exploratórias a sujeito extrai as representaçōes dos atos no pensamento, assim ele consegue transpor o que aprendeu com a experiencia para uma nova situação, é a assimilaçąo recognitiva, Identifica-se este momento quando, por exemplo, o aluno se aventura a usar uma

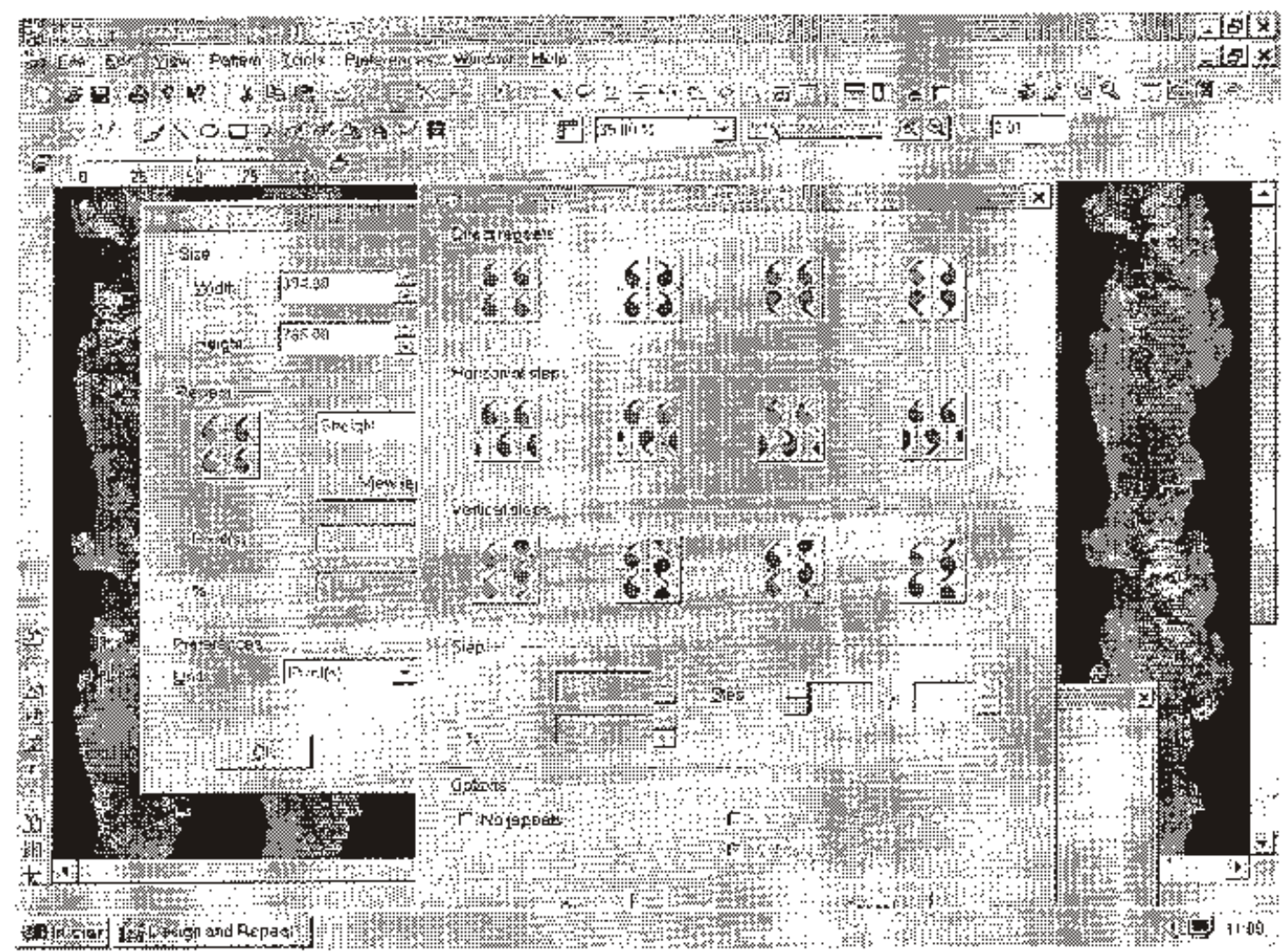

Esta tela mostra ativa a caixa de proprodades da imagem em que é possivel ad usuario escolher, dentre outras

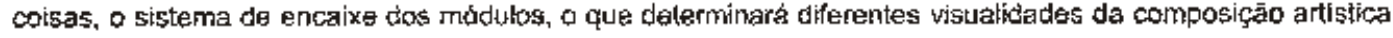


determinada ferramenta de desenho (ápis, pincel, preenchimento, etc) já dominada anteriormente para construir uma nova inagem.

O caminho adotado pelo sujeito cognitiwo vem da repeticäo, passa peja reflexäo com reconhecimento parte para a generalizaçăo, esterdendo o mesmo raciocínio adotado com êxito a una nova aplicaçăo. Na próxima etapa ele se permitirá fixar "um objetivo antes de poder alcança-lo e ufilizará diferentes esquernas de assimilaçäo como meios para lá chegar" (PIAGET, 1990). Quanto à exploraçäo das ferramentas oferecidas pelo programa gráfico em estudo notanos que a trarsiçäo da etapa anterior para essa (epigênese) utiliza un espaco de tempo maior, isto é o aluno somente se aventura a projetar um trabalho guando ja tem bastante experiencia (grande série de tentativas com erros e acertos) e se sente dominando as operaçōes das ferramentas. $O$ sujeito extrai do rasultado as rełaçōes de ordem encaderamento das açōes necessárias para atingir deteminado objetivo, é a retro-alimentaçāo desta coordenaça, sāo condutas instrumentais adquiridas. Quando o aluno sente segurança nos efeitos esperados das operaçōes controladas parte para combinaçōes inusitadas. Assim novas coordenaçöes oontinuam a surgir", refinardo os "instrumentos de froca" entre o sujeito e objeto, projetando um longo caminho evolutivo ate que as aços sejam interiorizadas e registradas sob a forma de "operaçes". Em outras palawras, identificamos que nesta etapa o alumo ja consegue fazer mas ainda näo sạbe explicar. Ele está utilizando esquemas da inteligéncia sensóriomotora que só entram em açäo no momento de sua aplicaçăo prática e material, nâo podendo ser manipulado pelo pensemento de forma abstrata e livre.

Será preciso que o sujeito reconstrua as açoes interiorizadas, projetando-as no patamar superior de representaçáo mental, com a ajuda da funçäo semiótica de "dar nomes" ás colsas, criar os conceitos que podem ser manipulados pela linguagem. Plaget denomina de "abstraçăo refiexiwa" a capacidade do sujeito em extrair das estruturas inferiores o necessário a construçäo de estruturas superiores, fornecendo elementos pata relaçóes de encaikes e de ordem. Nesta etapa, ro andamento do processo de conthecimento da linguagem do design de superficie através de programa gráfico, notamos que o aluno que já consegue colocar em pakaras seus ansejos busce a ajuda de colegas. É durante a busca da explicaça causal dos eventos que o sujeito consegue efetuar simultaneamente a sintese operatória e sua atribuicóo aos objetos relacionados.

Neste ponto estabelecese a cooperaçăo e colaboraça entre os alumos. O processo inferiorizado no sujeito se abte e o compartilhamento das sxperiencias de cada sujeito impulsiona de maneira definitiva o processo de aprendizado indihidual, obsevando-se uma grande aceleraçăo. No momento em que a palawra se constitui instrumento de intercambio entre os sujeitos, estes säo capazes de evocar eventos passados, presentes e futuros, projetando açōes possivejs no sentido de realizaça da vontade criativa, discutindo com os colegas e orientadora os melhores caminhos a adotar para ter sucesso com seu projeto grafico.

\begin{abstract}
"Qurante o processo de crtaçăo acontecern encadeamentos probabilisticos e aleatórios de idélas visuais. Encadeamentos probabilisticos porque resultam de escothas racionais e lógicas, fiuto do aprendizado 0 das leis que regulam a percepça humana; aleatónos porque as escolhas decorrem de processos de associaço de ideias que emergem sincronisticamente. Estes encadeamentos possibilitam a tomada de conscisncia dos eventos significatios que ocorrem e que caracterizam as escolhas realizadas durante o processo de criaço." (S|LVA, 1995)
\end{abstract}

No parágrafo acima Tânia Fraga da Silva aproxima-se das reflexöes de Piaget quanto à irłportância da tomada de consciéncia no dominio do processo. Isto é, quando o sujeito atinge o nivel das operaçöes formais, seu conhecimento supera o próprio real e pode estabelecer relaçóes sobre relaçōes, operaçöes sobre operações, trabahar com pbjetos hipotéticos, imaginârios da mente criativa do artista.

Q "possivel" para Piaget "năo é algo observável, mas o produto de ume construçăo do sujeito, em interaçăo com as propriedades do objeto" (PIAGET, 1985). Através do uma açăo formadora o raciocínio do artista consegue atticular qualidades sensoriais, afethas, facionais, intuitivas presentes em sua memória, atualizando as no campo dos acontecimentos (mesmo que anda em nivel wirtual) na tela do computador. O resultado e o desenvowimento exponencial de gamas de "possiveis" a serem explorados, afualizando-se na tela com facilidade inúmeras variaçōes da mesma imagem. Esta é uma característica fundamental das ferramentas computacionais, a de näo só fomentar a proliferação de novos repertârios visuais poéticos, como também de atualizá-los com facilidade. isto e, a simulação como recurso visual de antecipaçăo dos resultados possibilita ao usuáio opçōes de escotha e seleçäo dos resultados mais significativos para cle naquele momento.

No final de un semestre acadêmico, ou seja, aproximadamente oitenta horas-aule, observamos que os alunos, mesmo os que nunca haviam usado o computador com instrumento artistico, cotiseguiram expressar 
suas idélas, fazer suas escolhas e atualizar seus trabalhas (realizados virualmente) em impressōes das imagens que revelam, cetamente, uma ampliaçāo de seı vocabulário visual. Cabe ainda destacar o caràter radicaimente diferente destas imagens "simuladas" que fazem das imagens impressas apenas uma das atualizaçoes do "possível".

\section{Estudo de caso}

Apresentamos aqui o estudo de um caso especifico que nos charnou atençáa por se tratar de uma aluna que, apesar de já ter longa experiéncia arística, nẩo havia trabathado com computador ate aquele mofnento, nem possuía conhecimento algurr da linguagem do design de superficie.

Familiarizada com a metodologia experimental, a aluna sentiu-se a vontade para explorar seu novo universo. Ao ser perguntada sobre quals crił́rios havia estipulado para desenvalver sua investigaçăo, respondeu que não havia traçado um caminho anterior, que apenas tinha como poito de partida as fotografias que havia tirado das crianças de uma escola primária. O que a motivou foi a possibilidade de tratamento das imagens oferecido pelos recursos tecnologicos, apontando como uma perspectiva de ampliaça dos códigos poeticos fotográficos. Ela queria "ir além do 'click", ou seja o instante do registro da máquina que congela a imagem capturada. A sistemática adotada foi de ter previamente suas imagens escanerizades depois exportadas para o Design \& Repeat. Quando a imagem abria, jả estava colocada em repetiçáa (caracterlstica do programa), ela entāo buscava ampliar a magem para poder perceber methor o efeito da repetiçăo, para tal se utilizava do comando "view", indo até "zoom in lout", que e a fertamenta que possibilita a alteraçăo de escala da imagem. Neste ponto a aluna coloca sua dificuldade frente a interface do programa ser toda na lingua inglesa e ela nāo entender o significado das palavras. Este aspecto foi identificado como mais um obstáculo a ser superado, compondo como luma das ražcos pela qual ela näo havia preestabelecido uma trajetória exploratória definida. Segundo suas palavras usou apenas o metodo de proceder uma açăo, obsenar o efeito produzido na imagem e julgar se "gosto ou häo gosto". Este passou a ser o criterio de "salvar" ou eliminar a alteraçäo na forma. A etapa "salva" poderia seguir sendo trabalhada, isto e, experimentar outras alteraçós oferecidas pelas funçōes do sistema, que ela náo sabia serem possiveis. As vezes se lembrava de verificar se saberia repetir aquela açäo. Tentava recolocar o problema, abria o afquiwo e buscava a mesma seqüancia que pensava ter feito, se errasse continuava tentando até conseguir. Segundo Praget (1985) "do ponto de vista dos possiveis, um erro corrigido pode ser mais fecundo para as aberturas ulteriores do que um sucesso imediato". Outras vezes ficava tao deslumbrada com as possibilidades atualizadas na tela que seguia buscando cada wez mais "espetáculos" desconhecidos sem se importar em registrar o caminho que havia feito para chegar até la. Mesmo assim ela estava estendendo os limites possiveis do repertório visual instalado em sua mente, pois as operaçoes programadas previamente no sistema diziam respeito a códigos especificos de uma linguagem visual também desconhecida desta atuna, portanto a importáncia destes momentos se apoia no fato dela buscar os limites da linguagem multo majs que o domínio das femamentas.

Desta alternancie de foco de sua exploraçă foi construindo seu conhecimento, tecendo os dois: o uso adequado das ferramentas e o domínio da nova linguagem.

Quando perguntada se tem consciencia de suas açoes, responde que "agora sim", pois consegue repetir quando quiser e sabe até explicar para algum oolega como chegou a determinado resultado plástico. Diz que só se apercebia que já havia aprendido quando năo precisava majs pedir ajuda a algum colega.

Das suas interaçōes com o software levava para casa apenas os suportes eletrónicos (disquetes e cartucho de zip). Na metade do semestre the foi solicitado que apresentasse o testemunho de sua trajetoria e que projetasse um trabalho que se sentia apta a executar, simulando uma aplicacáo do design de superficie. Sua reaçāo foi de apreensāo pois julgava que nada havia feito durante todo o período exploratorio. Foj-lhe sugerido revisitar os arquivos "salvos" e imprimir as imagens meles contidas. A aluna ficou completamente surpresa e satisfeita com o quanto ela havia trabalhado e que provevelmente näo tinha tomado consciéncia do fato, primeiro porque o trabalho the pareceu prazeroso, um jogo lúdico, segundo porque năo via o resultado, pois se encontrava wituakizado. Ao serem atualizadas suas imagens a aluna pode analisar a sequencia das etapas por ela percorridas e se sentiu segura para fazer um projeto para o trabalho conchusivo das tarefas do semestre, que executou com tranqüilidade. De uma "direça sem finalismo" (Piaget) ela chegou a equilibraçå de suas estruturas cognitivas. 


\section{Conclusão}

Ointuito deste trabalho foi o de lançar um olhar sobre o possivel entendimento do fenomeno observado e estabalecer convergencias existentes entre os campos do conhecimento epistemológico e artistico.

Dentre os aspectos que emergiram durante a experiência prática realizada se apresenta o fato de que os trabalhos executados frouxeram como o resultado formal construçöes advindas da interaçäo homem-máquina, com a propriedade particular de se imporem como independentes assim que săo concluidas. A especulação desta observaçāo poderá ser ircrivelmente fecunda do ponto de vista do entendimento da criaçêo artística auxiliada pelas novas tecnologias.

Os fundamentos teóricos delineados neste ensajo buscaram apontar para algumas possiveis respostas de camo ocorte o fenômeno do aprendizado através da interaçāo com o computador diante do fato observado. Com certeza apenas indicaram caminhos possiveis que deveräo ser percorridos novamente visando o aprofundamento das questöes. $E_{1}$ como nos coloca Plaget (1985), quando chegamos a um patamar de entendimento abrimos para novas possibilidades, ou seja "a atualizaçăo de uma açz̄o ou de uma idéia pressupāe que antes de tudo elas tenham sido tornadas 'possiveis' e a observação mostra que o nascimento de um possher geralmente provoca outros". É a garantia da evoluçâo. Nesta abertura para novos possiveis surgem perguntas em nossa mente ainda hảo resolvidas como: quais são os edementos envolvidos na interação da lógica natural do sujelto e a tógica operacional da ferramenta computacional? Seria possivel identificar precisamente em cada sujeito qual o raciocinio criativo que o leva representar, simular ou refletir suas ideias graficamente na tela do computador? Serta possivel construir um método de análise para esses procedirmentos?

De acordo com o relatado anteriormente deduzimos que parece haver uma matriz cognitiva que o aluno inconscientemente utiliza. Essa matriz estaria de acordo con as etapas de desenvolvimento do conhecimento identificadas por Piaget e funciona como um caminho a ser seguido, como una lógica natural adotada pela maioria dos individuos diante de objetos desconhecidos. $O$ fato do objeto cognosclvel neste caso ser virtual, coloca uma primeira questāo, pois, segundo o pesquisador, o primairo instinto do sujeito é de sempre relacionar o objeto ao seu corpo, como forma primeira de conhecimento. Os ambientes eletrónicos alteram essa interação, distanciando o corpo do sujeito do objeto. $O$ objeto se toma intangivel e, ao mesmo tempo náo oferece as mesmas resistèncias dos objetos concretos. Por exemplo, em ambientes de realidade virtual podemos provocar uma colisăo con un objeto e nada sentimos, apenas chegamos täo perto que podemos enxergar sua composiçăo em pixels, sem sofrer as conseqüências normais causadas pelo impacto do objeto concrato.

O objeto colocado na dimensăo virtuat, isto é, na sua correspondente numérica, pelos meios eletrônicos se apresenta de uma nova maneira frente às interaçóes a que estávamos acostumados, tornando mais complexo o entendimento do processo cognitivo. Cabe pensar o que ocorre neste ambiente sintético de aprendizagem $\theta$ de que maneira o individuo se apodera do novo objeto? 0 que nos parece acontecer é que independentemente da natureza do objeto o sujeito motivado sempre ira se auto-organizar, buscando conhecer e dominar as regras do sistema computacional em jogo de forma a coloca-lo a seu serviço, ou nelhor, a serviço de sua mente criadora, que jà projeta soluçóes inovadoras, que, uma vez disponibilizadas neste mundo, contribuem e/ou influenciam de alguma maneira. Seria o que chamamos de autopoiese. Para Fiaget (1977), o aluno nos dà provas de que aprendeu quando inventa ou descobre algo novo em relaçäo ao objeto de seu interesse.

Outra constataçăo que se apresenta é que parece existit dois formatos bógicos que atuam em conjunto e se complementam. Talvez correspondam às caracteristicas distintas dos dois hemisférios cerebrais: o esquerdo, mais racional, e o direito, mais emocional. Seria a existência de uma lógica do raciocinio e uma lógica da craçäo, sendo que a base maternática parece permear os dois caminhos, isto é, a matemática como a linguagem abstrata de entendirnento do espirito, como nos coloca Piaget: "ela the permite estruturar o reat e deduzir os fenômenos, sem şe limitar a constatä-los" (PIAGET, 1973). A lógica como é conhecida no uso comum se apresenta como um método que se oferece às demajs cièncias para ajudar a conhecer seu objeto de estudo. Hoje reconhecemos o processo artistico tambérn como um método de investigaçāo, descoberta $\theta$ exploração de novos limites da consciēncia humana, só que, enquanto a tógica puramente racional garante a objetividade e rigor cientifico, a arte contribui de maneira peculiar visando despertar o saber subjetivo e sensorial. Busca expressar e compreender fenomenos singulares, impossiveis de serem colocados em palavras (inefáveis), idiossincrasias, espeficificidades e atè mesmo paradoxos (StLVA, 1995). A arte como meio de explorar a realidade prepara o homem contemporâneo para a possibilidade de experimentaçâa sensorial de novas dimensoes da realidade que as novas tecnologias computacionais estão revelando e fomentando. 
Acredjamos que Piaget terá seu lugar garantido como formulador de leis lógicas que intervém de forma vetorial nesta busca que se coloca, como uma "direçăo orientada" apontando para o futuro. Quando constatamos, mais uma vez sua razäo quando diz que sempre que procuramos as causas de uma asserçäo ou de um fenômeno seremos conduzidos a soluçóes que levantarāo nowos problemas que clamam por novas soluçŏes, e assim por diante (PIAGET, 1978).

\section{Referèncias bibliogräficas}

BEHAR, Patricia Alejandra. Análișe Operatória de Ferramentas Computacionais de Uso Individual e Cooperativo. Têse de Coutorado em Ciência da Computaçäo, UFRGS, 1998.

MATURANA, Humberto e Frantisco Varela. De Máquinas e Seres Vivos, Autopoiese: a organização do vivo, Porto Alegre: Artes Médicas, 1997.

PIAGET, Jean. Fazer e Compreender. Sāo Paulo: Melhoramentos; 1978.

. A tomada de consciência. São Paulo: Nelhoramentos, 1977.

O desenvolvimento do pensamento: equilibraçăo das estruturas cognitivas. Lisboa: Dom Ouixołe, 1977.

O possivel e o necessário:Vol. 1. Porto Alegre: Artes Médicas, 1985.

Epistemologia Genética. Săọ Pauta: Martins Fontes, 1990.

Biologia e Conhecimento: Ensaio sobre as relaçōes entre as regulaçöes orgânicas os processos cognoscitiwos. Petrópolis: Editora Vozes, 1973.

SILVA, Tânia Regina Fraga da. Simulaçōes Estereoscópicas Interativas.

http://www.lsi.usp.bri-tania/po.html, acessado em setembro de $\$ 999$.

http://www.Isl.usp.br/si/art/art.html, acessado em setembro de 1999. 